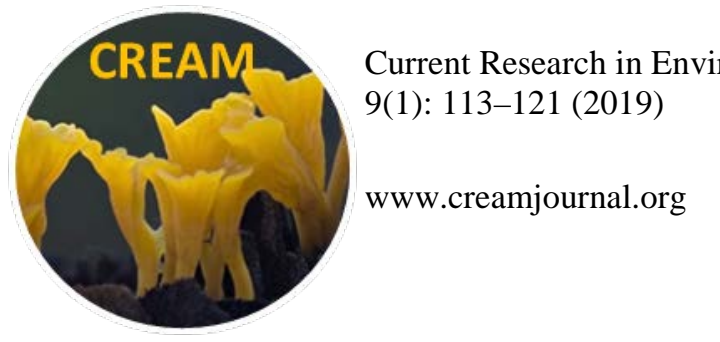

ISSN 2229-2225

\title{
Efficacy of foliar spray applications of plant extracts against groundnut rust
}

\section{Kamble SK* and Patil BJ}

Department of Botany and Plant Protection, Sadguru Gadage Maharaj College, Karad, Dist- Satara. Pin Code415124, (M. S.) India.

Kamble SK, Patil BJ 2019 - Efficacy of foliar spray applications of plant extracts against groundnut rust. Current Research in Environmental \& Applied Mycology 9(1), 113-121, Doi 10.5943/cream/9/1/12

\begin{abstract}
An attempt has been taken to control groundnut rust disease caused by Puccinia arachidis Speg. using foliar spray applications of plant extracts under field condition. A new formulation, 'Panchaparni extract', was developed using leaf extracts of Eupatorium odoratum L., Eucalyptus globulus Labill., Azadirachta indica A. Juss., Vitex nigundo L. and Datura metel L. to control rust of groundnut. The Panchaparni extract was observed to be most effective than all other plant treatments and control (distilled water spray) which reduced the percent disease index and increased the efficiency of percent disease control.
\end{abstract}

Key words - botanicals- foliar spray - disease

\section{Introduction}

The leaf rust of groundnut caused by Puccinia arachidis Speg. was first recorded in the Maharashtra state of India during 1973-74 (Patil \& Kalelkar 1974, Shinde \& More 1975). The rust disease assumed epidemic proportions in 1976-77 and has been economically important in all groundnut-growing areas of the state (Garud et al. 1976, Mayee 1982). The development of elliptical infection centers governed by the wind direction prior to the large-scale spread of rust has been demonstrated (Mayee 1983). The inoculum from these areas could be important in the epidemiology of the rust disease in Maharashtra.

Chemical fungicides are used to control the rust disease. Kemerait et al. (2007) recommended a variety of fungicides with different modes of action such as Organochlorines (e.g. Chlorothalonil), Triazoles (e.g. Tebuconazole and Propiconazole), and Strobilurins (e.g. Trifloxystrobin and Pyraclostrobin) for the management of peanut leaf spot and rust in Georgia. Gangopadhyay et al. (1996) observed an increase in germination percentage and pod yield due to controlling the leaf spot intensity of groundnut through the application of fungicidal spray and seed treatment.

In addition to that, Vyas (2003) stated that extensive use of systemic fungicides have led to several problems of toxicity, hazards to living beings, development of resistance in pathogen and non-target effects of wide-ranging fungicides on allied soil micro-flora. The exploitation of fungicides is also restricted to production for export markets. However, several fungicide applications required and high production costs are often considered impractical and not sustainable (Steadman et al. 1995). By considering the harmful effects of fungicides on environment and 
health, the use of alternative methods is necessary to find out. Plant extract is a new approach that showed promising results in controlling certain diseases including wheat leaf rust with less environmental pollution (Joseph \& Sharia 1999).

The aqueous extract of Azadirachta indica leaves was found more effective against the rust of groundnut caused by Puccinia (Ghewande 1989). Singh \& Narayana (2002) reported that, neem formulation PJMC was effective in managing rust of French bean caused by Uromyces appendiculatus. There is a great scope for utilization of various plant extracts against rust. Therefore, an experiment was conducted in field condition to control rust of groundnut using plant extracts.

\section{Material \& Methods}

\section{Field visits and Collection of samples and plants a source of extract}

Frequent visits were organized to agricultural fields of different localities in Satara district for the survey and collection of rust disease on groundnut. The groundnut rust infected leaves were collected during rainy and summer season (Fig. 1). The rust infected leaves from various crop fields of Satara district were collected in the rainy season and brought to the laboratory for further studies. The plants viz., Eupatorium odoratum, Eucalyptus globulus, Azadirachta indica, Vitex nigundo, Datura metel, Croton bonplandianus, Ageratum conyzoides, Phyllanthus reticulatus, Achyranthes aspera, Argemone mexicana, Tridax procumbens, Azadirachta indica etc. were collected from agricultural fields of Satara district and brought to the laboratory for the preparation of extracts.
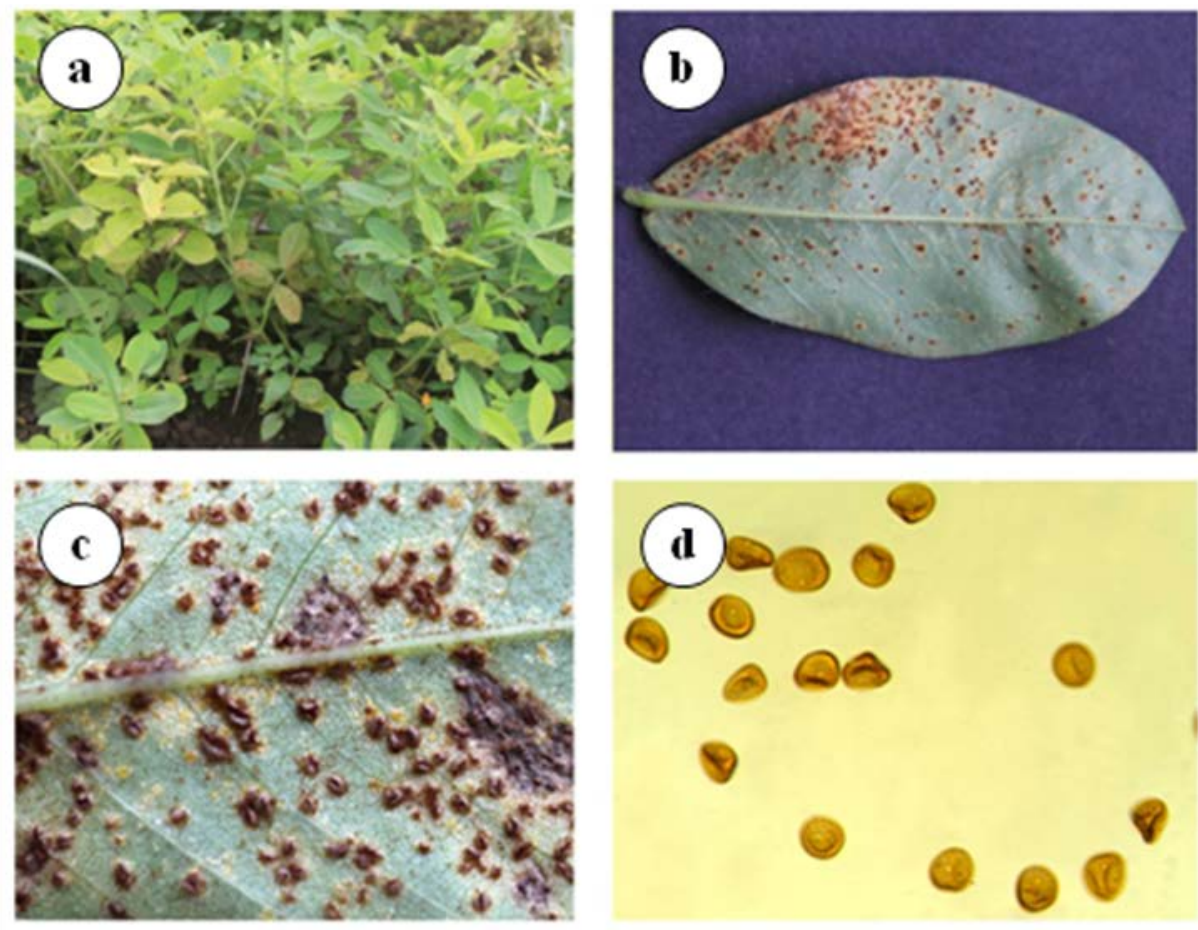

Fig. 1 - Groundnut rust. a Rust on groundnut. b Rust pustules on the leaflet. c Enlarged rust pustules. d Urediospores.

\section{Preparation of plant extracts}

The aqueous extracts were preferred for the experimental purpose. The leaves of different plants were washed with tap water and blotted to dry. Five hundred grams of each selected plant material was crushed in a mortar with pestle and extracted in $500 \mathrm{ml}$ sterile distilled water. The extract was filtered through four layered muslin cloth. The filtrate was centrifuged at 1600 RPM for 5 minutes to avoid debris. The equivalent quantity of leaves of Eupatorium odoratum, Eucalyptus globulus, Azadirachta indica, Vitex nigundo and Datura metel (1:1:1:1:1) were used to prepared 
aqueous 'Panchparni extract'. The supernatant was considered as a stock solution. The plant extracts of $7 \%$ concentration were made by adding distilled water. The distilled water spray was used as a control. The chemical fungicide Propiconazole $(0.1 \%)$ was used as a standard check.

\section{Field experiments}

\section{Randomized Block Design}

A field experiment was conducted in the first week of February 2015 for the evaluation of plant extracts against the groundnut rust. Groundnut variety SB XI was sown in a farm of a village, Vanvasmachi located in the Karad tehsil (Fig. 2). The experiment was arranged with ten treatments and three replications in 1x $1 \mathrm{~m}$ plot size (Table 2). The totals of ten treatments by keeping three replications were selected for the spray to check of groundnut rust (Table 1). The plant extracts and 'Panchparni Extract' was freshly prepared on the day of foliar application and used for the sprayings. The total three sprayings were carried out, on naturally originated rust infection. The first spray of treatments was employed at the time of initiation of disease i.e. 55 days after sowing. The second and third sprayings were taken after the interval of fifteen days i.e. 70 and 85 days after sowing.
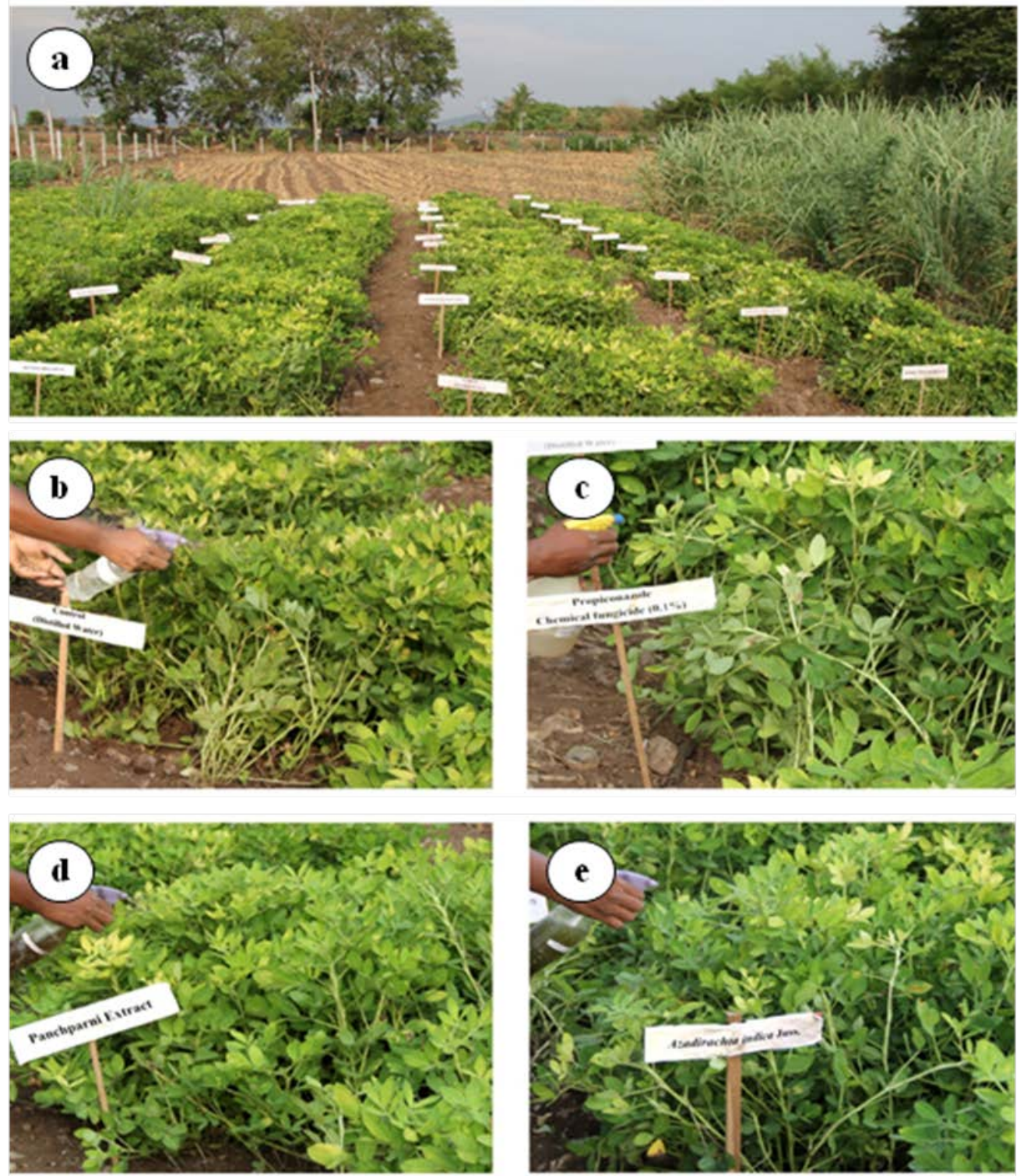

Fig. 2 - Randomized Block Design. a Treatments used for the spray. b Control (Distilled Water). c Propiconazole (0.1\%). d Panchparni extract. e Azadircahta indica. 
Table 1 The treatment details for groundnut rust.

\begin{tabular}{cc}
\hline Treatment No. & Name of Treatment \\
\hline T1 & Croton bonplandianus \\
T2 & Ageratum conyzoides \\
T3 & Phyllanthus reticulatus \\
T4 & Achyranthes aspera \\
T5 & Argemone mexicana \\
T6 & Tridax procumbens \\
T7 & Azadirachta indica \\
T8 & Panchparni extract \\
T9 & Propiconazole $(0.1 \%)$ \\
T10 & Control (D. W.) \\
\hline
\end{tabular}

Table 2 The plan of layout for groundnut rust.

\begin{tabular}{ccc}
\hline RI & RII & RIII \\
\hline T9 & T3 & T8 \\
T6 310 & T3 \\
T3 & T4 1 \\
T8 & T4 & T7 \\
T1 & T7 & T4 \\
T10 & T9 & T2 \\
T4 & T1 & T6 \\
T7 & T5 & T9 \\
T5 & T8 & T10 \\
\hline
\end{tabular}

\section{Evaluation of disease intensity}

The efficacy of each phytofungicide was tested as compared to the control plot sprayed with distilled water. The intensity of the disease was recorded by randomly selecting five plants from each plot. From each plant, five leaflets from the top, middle and bottom portions were chosen for recording observations. The percentage of disease intensity was examined by using a 0-9 scale as given below (Mayee \& Datar 1986).

$0=$ No pustules

$1=1-10 \%$ leaflet area covered with rust pustules

$3=11-25 \%$ leaflet area covered with rust pustules

$5=26-50 \%$ leaflet area covered with rust pustules

$7=51-75 \%$ leaflet area covered with rust pustules

$9=>75 \%$ leaflet area covered with rust pustules (Fig. 3)

Further, the percent disease index (PDI) and percent disease control (PDC) of the rust developed from the natural inoculums were observed at fifteen days interval after the appearance of the first symptoms and calculated by using Wheeler's (1969) formula.

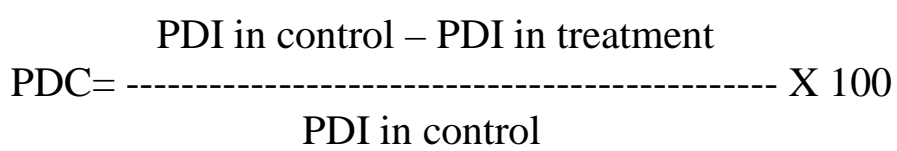


Where, PDI= Percent Disease Index

$$
\begin{gathered}
\text { PDI in control - PDI in treatment } \\
\text { PDC= }- \text { PDI in control }
\end{gathered}
$$

Where, PDC= Percent Disease Control and PDI= Percent Disease Index

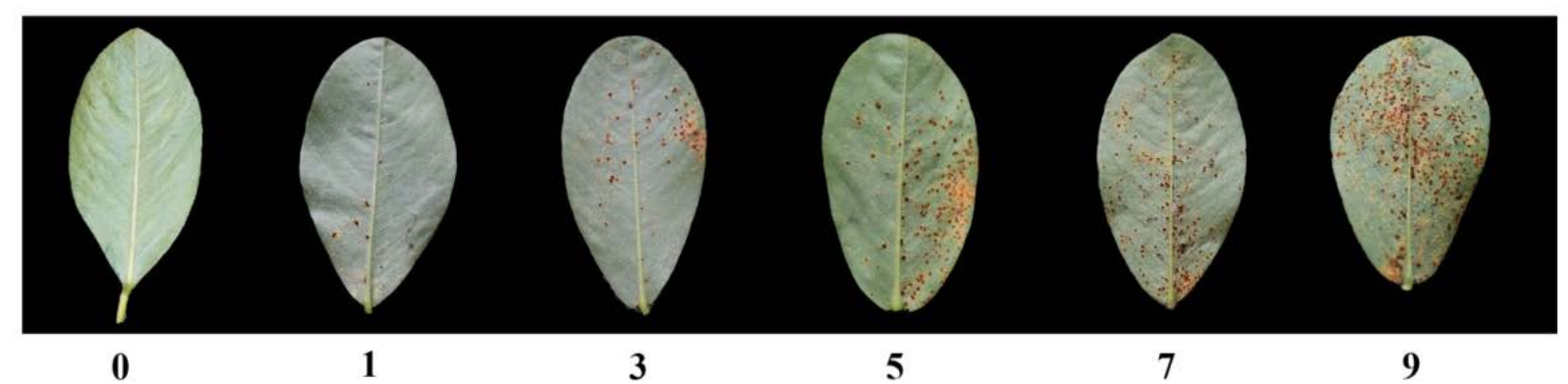

Fig. 3 - 0-9 Scale used to measure disease intensity of groundnut rust

\section{Statistical analysis}

Data were recorded from field experiments using suitable methods for randomized block design. Analysis of variance (ANOVA) on the data was performed and treatment means were separated using the Duncan's Multiple Range Test. The ANOVA was performed with SPSS 16.0 software. The standard error (S.E.) had been calculated. The effects were considered significant when the $\mathrm{P}$ value of the ANOVA test was $<0.05$.

\section{Result and Discussion}

Effect of plant extracts on the percent disease index (PDI) of groundnut rust

The percent disease index (PDI) after the foliar spray applications at different time intervals

\begin{tabular}{|c|c|c|c|c|c|}
\hline \multirow[t]{3}{*}{ Tr. No. } & \multirow{3}{*}{$\begin{array}{l}\text { Treatment } \\
\text { (7 \% extract) }\end{array}$} & \multirow{2}{*}{\multicolumn{3}{|c|}{$\begin{array}{c}\text { Percent Disease Index (PDI) } \\
\text { Days after sowing }\end{array}$}} & \multirow{3}{*}{$\begin{array}{l}\text { Pooled } \\
\text { Mean }\end{array}$} \\
\hline & & & & & \\
\hline & & 55 & 70 & 85 & \\
\hline 1 & Croton bonplandianus & $12.83^{f}$ & $24.93^{d}$ & $33.58^{\mathrm{e}}$ & 23.78 \\
\hline 2 & Ageratum conyzoides & $11.44^{d}$ & $24.44^{\mathrm{cd}}$ & $29.13^{c}$ & 21.67 \\
\hline 3 & Phyllanthus reticulatus & 12.09 de & $23.95^{\mathrm{cd}}$ & 32.34 de & 22.79 \\
\hline 4 & Achyranthes aspera & $15.55^{f}$ & $29.87^{\mathrm{e}}$ & $40.00^{f}$ & 28.47 \\
\hline 5 & Argemone mexicana & $11.60^{\mathrm{d}}$ & $22.96^{\mathrm{c}}$ & $31.11^{\mathrm{cd}}$ & 21.89 \\
\hline 6 & Tridax procumbens & $14.81^{\mathrm{f}}$ & $28.64^{\mathrm{e}}$ & $38.76^{f}$ & 27.40 \\
\hline 7 & Azadirachta indica & $9.13^{\mathrm{c}}$ & $17.77^{\mathrm{b}}$ & $24.19^{b}$ & 17.03 \\
\hline 8 & Panchparni extract & $7.65^{b}$ & $16.04^{\mathrm{b}}$ & $22.22^{b}$ & 15.30 \\
\hline 9 & Propiconazole $(0.1 \%)$ & $4.44^{\mathrm{a}}$ & $10.37^{\mathrm{a}}$ & $16.04^{\mathrm{a}}$ & 10.28 \\
\hline 10 & Control (D. W.) & $32.59^{g}$ & $57.69^{f}$ & $70.86^{\mathrm{g}}$ & 53.71 \\
\hline & $\mathrm{SE} \pm$ & 1.33 & 2.24 & 2.64 & 2.74 \\
\hline
\end{tabular}
is collectively represented in Table 3 and depicted in Fig. 4.

Table 3 Effect of foliar spray of plant extracts on Percent Disease Index (PDI) of groundnut rust. 
Note: Each value is a mean of three replicates. Means followed by the same letter along the column are not significantly different $(\mathrm{P}<0.05)$ using Duncan's Multiple Range Test, $\mathrm{SE} \pm=$ Standard error and D. W. = Distilled water

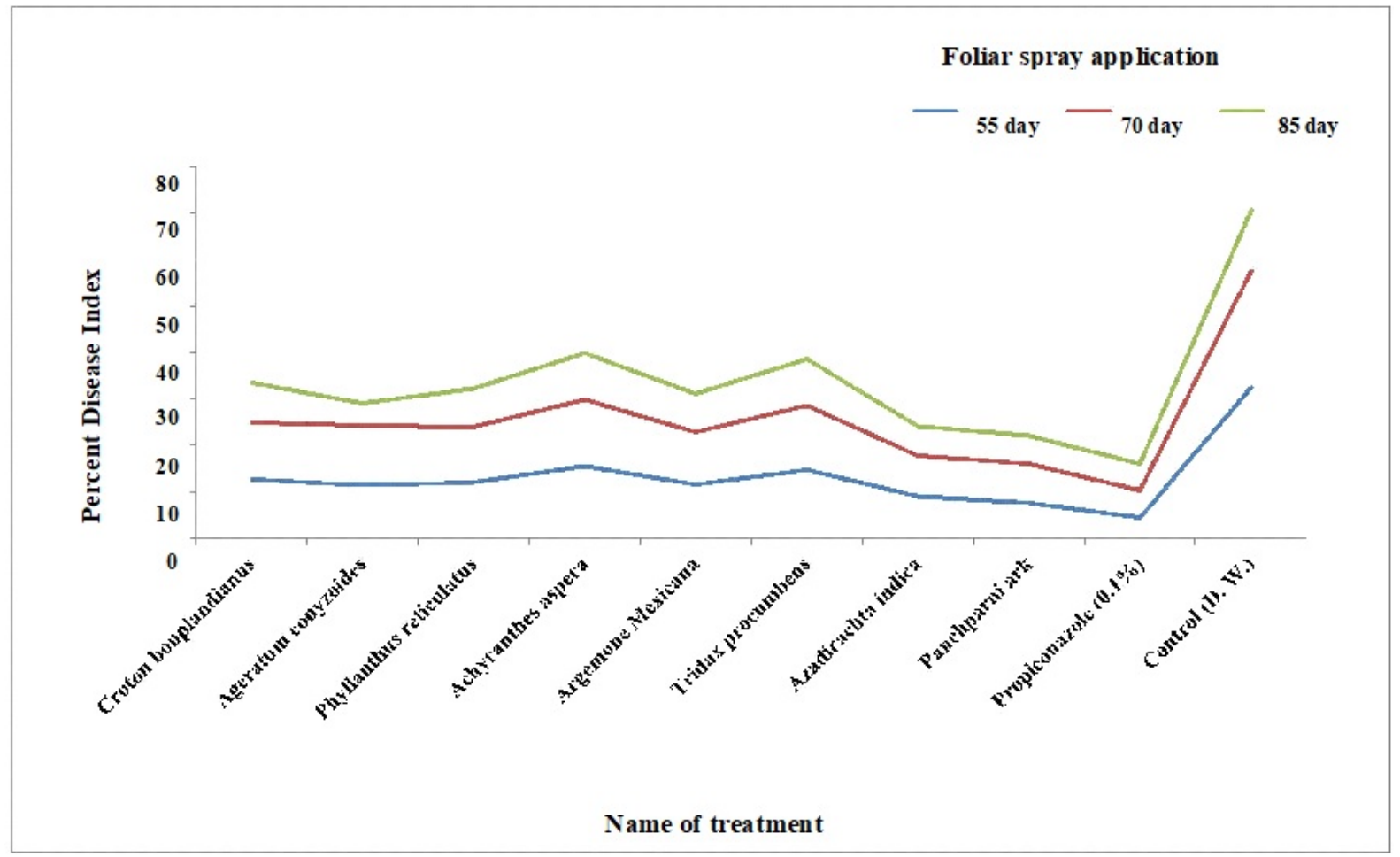

Fig. 4 - Effect of plant extracts on percent disease index of groundnut rust. Data points represent the mean values after $7 \%$ concentration of plant extracts at 55, 70 and 85 days after sowing.

An effective concentration, $7 \%$ of plant treatments was utilized for the foliar spray against the rust infected leaves of groundnut. The reduction in percent disease index i.e. incidence of rust was reported a sign of the better efficacy of treatment. The least percent disease index was observed after the first spray i.e. 55 days after sowing. The PDI was found increased after the subsequent time intervals i.e. 70 and 85 days after sowing. The maximum average disease index $53.71 \%$ was observed in distilled water spray (control). It showed 32.59, 57.69 and $70.86 \%$ disease index after 55, 70 and 85 days respectively. The foliar spray application of Propiconazole $(0.1 \%)$ was proved significantly superior over all other treatments. It showed the least average percent disease index i.e. $10.28 \%$. The disease indexes i.e. 4.44, 10.37 and $16.04 \%$ were observed on 55, 70 and 85 days after sowing respectively.

The Panchaparni and Azadirachta indica were found significantly higher over all the plant treatments and control which showed 15.30 and $17.03 \%$ average disease index respectively. The Panchaparni extract showed 7.65, 16.04 and $22.22 \%$ disease index on 55, 70 and 85 days after sowing respectively. Azadirachta indica lowered the average disease index to 9.13, 17.77 and 24.19 $\%$ on 55, 70 and 85 days after sowing respectively. Some other plant treatments were also found better effective against the groundnut rust. Remaining treatments were also effectively tested.

Sunkad et al. (2005) found that the foliar spray application of Propiconazole $(0.1 \%)$ on groundnut cultivar JL-24 during rainy season showed minimum percent disease index.

Yasser et al. (2016) proved that application of neem, clove and garden quinine extracts completely prevented rust development on wheat and was comparable with the fungicide Sumi-8. According to Mekonnen et al. (2014) Lantana camara L., Milletia ferruginea L., Eucalyptus globulus L., Maesa lanceolata L, Ruta chalapensis L., Vernonia amygdalina L. and Datura stramonium L. showed potential efficacy against spearmint leaf rust in field condition.

Pawar (2013) observed a significant effect of Argemone mexicana and Azadirachta indica in the reduction of percent disease index of jowor and wheat rust respectively. Yusnawan \& Inayati 
(2016) found correlated results with the present study i.e. $24.9 \%$ percent disease index after third foliar spray of $A$. conyzoides (5 \%) against groundnut rust.

\section{Effect of plant extracts on the percent disease control (PDC) of groundnut rust}

The effect of different treatments on percent disease control (PDC) of the groundnut rust after different time intervals of spraying is collectively represented in Table 4 and depicted in Fig. 5.

Table 4 Effect of foliar spray of plant extracts on Percent Disease Control (PDC) of groundnut rust.

\begin{tabular}{|c|c|c|c|c|c|}
\hline \multirow[t]{2}{*}{$\begin{array}{l}\text { Tr. } \\
\text { No. }\end{array}$} & \multirow[t]{2}{*}{$\begin{array}{l}\text { Treatment } \\
\text { (7 \% extract) }\end{array}$} & \multicolumn{3}{|c|}{$\begin{array}{c}\text { Percent Disease Control (PDC) } \\
\text { Days after sowing }\end{array}$} & \multirow[t]{2}{*}{$\begin{array}{l}\text { Pooled } \\
\text { Mean }\end{array}$} \\
\hline & & 55 & 70 & 85 & \\
\hline 1 & Croton bonplandianus & $60.60^{c}$ & $56.66^{\mathrm{c}}$ & $52.59^{d}$ & 56.61 \\
\hline 2 & Ageratum conyzoides & $65.13^{d}$ & $61.81^{\mathrm{e}}$ & $58.86^{\mathrm{g}}$ & 61.93 \\
\hline 3 & Phyllanthus reticulatus & $62.90^{\mathrm{cd}}$ & $58.37^{\mathrm{cd}}$ & $54.37^{\mathrm{e}}$ & 58.54 \\
\hline 4 & Achyranthes aspera & $52.29^{b}$ & $48.05^{b}$ & $43.55^{b}$ & 47.96 \\
\hline 5 & Argemone mexicana & $64.39^{d}$ & 60.09 de & $56.10^{\mathrm{f}}$ & 60.19 \\
\hline 6 & Tridax procumbens & $54.51^{b}$ & $50.23^{b}$ & $45.28^{c}$ & 50.00 \\
\hline 7 & Azadirachta indica & $71.97^{\mathrm{e}}$ & $69.09^{f}$ & $65.86^{\mathrm{h}}$ & 68.97 \\
\hline 8 & Panchparni extract & $76.48^{f}$ & $72.09^{g}$ & $68.66^{\mathrm{i}}$ & 72.41 \\
\hline 9 & Propiconazole $(0.1 \%)$ & $87.21^{\mathrm{g}}$ & $81.98^{h}$ & $77.33^{\mathrm{k}}$ & 82.17 \\
\hline \multirow[t]{2}{*}{10} & Control (D. W.) & $00^{\mathrm{a}}$ & $00^{\mathrm{a}}$ & $00^{\mathrm{a}}$ & 00 \\
\hline & $\mathrm{SE} \pm$ & 4.11 & 3.89 & 3.71 & 3.94 \\
\hline
\end{tabular}

Note: Each value is a mean of three replicates. Means followed by the same letter along the column are not significantly different $(\mathrm{P}<0.05)$ using Duncan's Multiple Range Test, SE $\pm=$ Standard error and D. W. = Distilled water

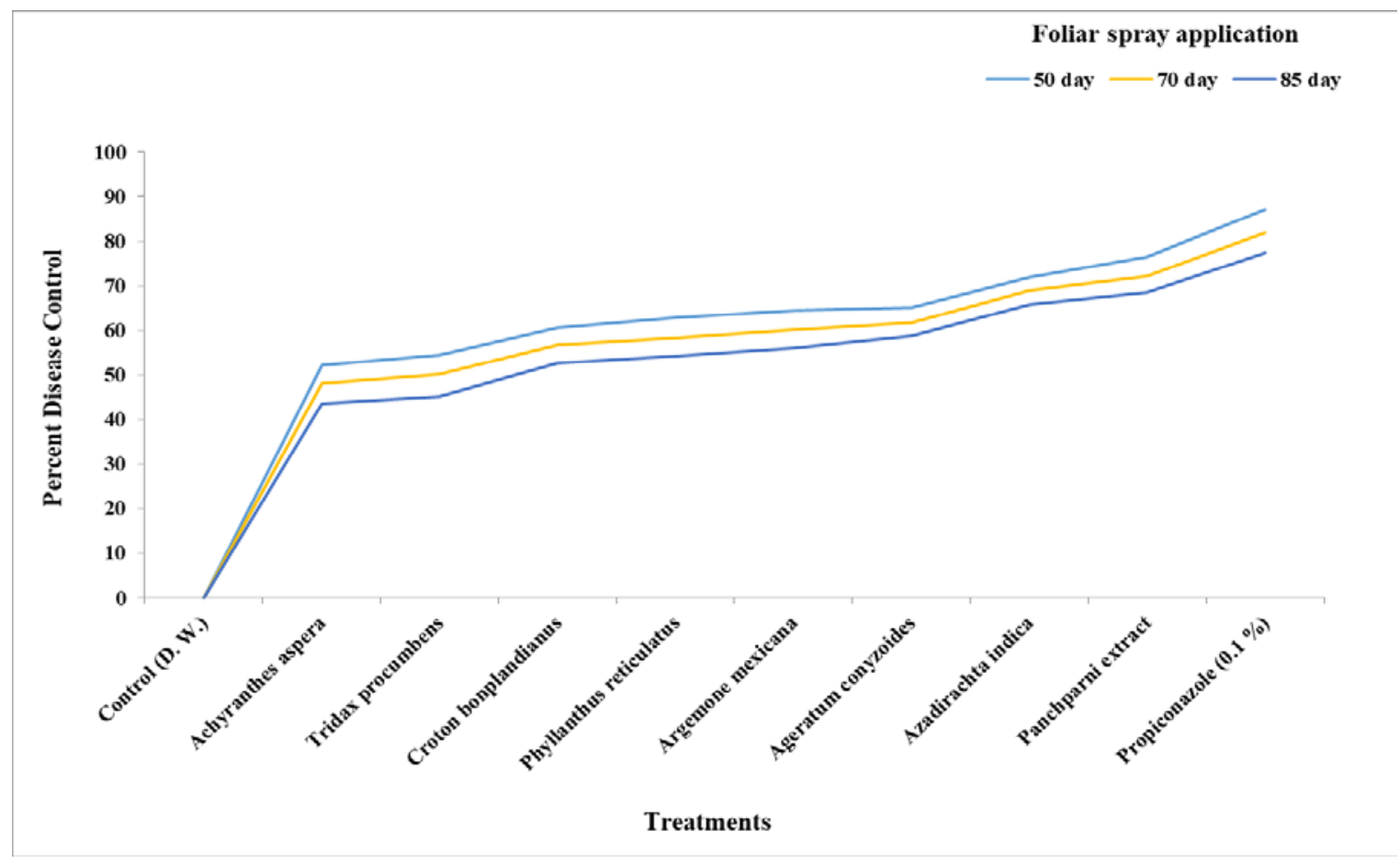

Fig. 5 - Effect of plant extracts on percent disease control of groundnut rust. Data points represent the mean values after $7 \%$ concentration of plant extracts at 55, 70 and 85 days after sowing.

The maximum percent disease control was observed after first spray i.e. after 55 days of sowing. The percent disease control was found to be decreased with the increase in time intervals 
i.e.70 and 85 days after sowing. The maximum percent disease control $87.21 \%$ was observed after the first foliar spray of Propiconazole (0.1\%).

The Panchparni extract and Azadirachta indica were found significantly higher over all other plant treatments and control which showed the 72.41 and 68.97 average PDC. Other plant treatments were also found noticeably in percent disease control. Ageratum conyzoides, Argemone mexicana, Phyllanthus reticulatus and Croton bonplandianus showed the better result in PDC i.e. 61.93, 60.19, 58.54 and $56.61 \%$ average disease control after foliar spray applications.

Pawar (2013) proved the efficacy of aqueous extract of Azadirachta indica and Argemone mexicana against jowor rust. Chandrashekara et al. (2012) used extracts of Azadirachta indica, Carica papaya, Ocimum sanctum, Phyllanthus niruri and Vitex nigundo against leaf rust of mulberry. Chhetry \& Mangang (2012) tested aqueous extracts of Artemisia vulgaris, coix lacrymajobi, Lantana camera, Michelia champaca, Passiflora foetida, Punica granatum and Strobilanthes flaccidifolius against the Rhizoctonia solani causing root rot of French bean. Lantana camera was showed superior activity followed by Michelia champaca, Passiflora foetida and Coix lacrymajobi.

Subramani et al. (2012) reported better efficiency leaf extracts of Adathoda vasica, Lantana camara and Azadirachta indica against rust of coffee. Hasan et al. (2014) found significant results after the foliar spray application of Azadirachta indica, Polyalthia longifolia and Datura metel against the leaf spot of groundnut.

\section{Conclusion}

All the plant extract treatments were found superior against rust disease of groundnut as compared to control (distilled water spray) in the field. Moreover, Panchpaparni extract was most effective due to the combined effect of five leaf extracts of different plants. This formulation is made up of botanicals and several researchers recommended such eco-friendly formulations for control of variety of diseases on crops. Therefore, farmers should use such formulations.

\section{References}

Chandrashekara KT, Prakash BM, Mahesha KS, Rajasekhar N. 2012 - Antifungal activity of plant extracts against leaf rust disease of mulberry. Journal of Sericulture Technology 3:60-63.

Chhetry GK, Mangang HC. 2012 - Evaluation of ecofriendly management practices of French bean rust (Uromyces appendiculatus) in organic farming system. International Journal of Advancements in Research \& Technology 1(4):2278-7763.

Gangopadhyay S, Bhatia JN, Gadora SL. 1996 - Comparative efficacy of fungicides in controlling leaf spots of groundnut in India. International Arachis Newsletter 16:33-34.

Garud TB, Patil FS, Khalikar PV, Mayee CD. 1976 - Groundnut rust epidemic, FAO Plant Protection Bulletin 24:1333.

Ghewande MP. 1989 - Management of foliar diseases of groundnut (Arachis hypogaea) using plant extracts. Indian Jornal of Agricultural Sciences 59:133-144.

Hasan MM, Islam MR, Hossain I, Shirin K. 2014 - Biological control of leaf spot of groundnut. Journal of Bioscience and Agriculture Research 1(2):66-78.

Joseph Kumari TS, Sharia BP. 1999 - Medicinal plants in pest control. Indian Journal Arecanut, Spices and Medicinal plants 1:123-124.

Kemerait Jr. RC, Brenneman TB, Culbreath AK. 2007 - Peanut Disease Control. In: 2007 Georgia Pest Management Handbook, P. Guillebeau, ed. University of Georgia Cooperative Extension Series, Athens, GA.

Mayee CD. 1982 - Groundnut rust: a review, Indian Botanical Reporter. 1:75-83.

Mayee CD. 1983 - Epidemiology and forecasting of groundnut rust in Marathwada region: final report. Parbhani, Maharashtra, India: Marathwada Agricultural University. pp. 76. 
Mayee CD, Datar VV. 1986 - Phytopathometry. Tech Bulletin. 1 (Special Bull 3). Marathwada Agriculture University, Parbhani (Maharashtra) p. 66.

Mekonnen M, Manhile B, Meng B. 2014 - Screening of Botanical Extracts for the Control of Spearmint Leaf Rust in Greenhouse and Field Conditions, World Journal of Agricultural Sciences 10(2):42-47.

Patil BP, Kalekar AR. 1974 - Effect of seven fungicides and antibiotics on leaf rust of groundnut (Puccinia arachidis Speg.). Pesticides 8:23-25.

Pawar DS. 2013 - Studies on antifungal activity of some plant extracts on spore germination in wheat and jowor rust. A Ph. D. thesis submitted to Shivaji University, Kolhapur. pp. 123.

Shinde PA, More WD. 1975 - Outbreak of groundnut rust at Rahuri. Research Journal of Mahatma Phule Agricultural University 6:75-76.

Singh AK, Narayana BM. 2002 - Control of frenchbean rust through fungicides and a neem based formulation. Indian Phytopathology 55(2):241-243.

Steadman JR, Beaver J, Boudreau M, Coyne D et al. 1995 - Progress reported at the $2^{\text {nd }}$ International Bean Rust Workshop. Annual Report of the Bean Improvement Cooperative 38:1-10.

Subramani D, Rajanaika K, Chinnaswamy KK, Singh S et al. 2012 - Comparative efficacy of plant products on the spore germination and disease incidence of coffee leaf rust pathogen. Acta Biologica Indica 1(1):69-75.

Sunkad G, Mesta RK, Reddy M. 2005 - Field efficacy of some fungicides for effective and economical control major foliar diseases of groundnut. Karnataka Journal of Agricultural Sciences 18(4):995-997.

Vyas SC. 2003 - Handbook of systemic fungicides. Tata McGraw Hill Co. Ltd., New Delhi, pp. 45-47.

Wheeler BEJ. 1969 - An Introduction to Plant Diseases. John Wiley and sons Ltd. London, pp. 301.

Yasser SM, Abdalla ME, Atef AS, El-Sawy MM et al. 2016 - Efficacy of plant extracts in controlling wheat leaf rust disease caused by Puccinia triticina, Egyptian Journal of Basic and Applied Sciences doi: 10.1016/j.ejbas.2016.09.002.

Yusnawan E, Inayati A. 2016 - Methanolic extracts of three weeds as botanical fungicides to control peanut rust disease. Nusant Ara Bioscience 8(1):117-122. 